\title{
Socio-economic Impacts of Smallholder Dairy Cattle Farming on Livelihood in Sunga Ward of Lushoto District, Tanzania
}

\author{
Emmanuel Paul Mzingula \\ Tanzania Network for Green Initiatives \\ Email: mzingula@yahoo.com
}

\begin{abstract}
A smallholder dairy cattle farming has been practiced by farmers in Tanzania, particularly in rural areas as a means of livelihood through income generated and food security although information about its impacts might not be clear from different locations. This study examined socio-economic impacts of smallholder dairy cattle farming on the livelihood in Sunga ward of Lushoto District, Tanzania. A cross-sectional study design was adopted whereby quantitative approach was used. Simple random sampling was used to select 120 households from 384 total households practicing dairy cattle farming. The survey was used as the method of data collection. Structured questionnaire constructed from close and open ended questions was utilized as an instrument of data collection. Data analysis was done by using SPSS whereby the study revealed descriptive statistics and paired-samples $t$ test. Results show that smallholder dairy cattle farming has a social impact on household food security due to increased crop yields (97.5\%), milk consumption (74.8\%) and selling of cattle (67.2\%). Also, households improved access to education (79.2\%), improved access to health services (84\%) and increased assets $(87.4 \%)$ such as buying of land, motorcycles and construction of houses. Moreover, dairy cattle farming has demonstrated economic impacts through direct income generated from selling milk (65.8\%), using manure for agriculture (100\%), income from selling cattle (71.7\%) and perceived as a source of employment (92.5\%). Income from selling milk contributes about $47 \%$ of annual income of the household. Through cattle manure application on cropping farms, average household annual income in Tanzania shillings (TZS) generated from crops was significantly increased to TZS 555300 from TZS 166600 in the period before household introduced cattle manure $(\mathrm{t}=10.188, \mathrm{p}<0.001)$. This study recommends the government to allocate more extension officers in rural areas, particularly in Sunga ward in order to enhance knowledge and skills of farmers that can help to improve further their efficiency in dairy cattle rearing so as to increase their income and enhance food security for sustainable livelihood.
\end{abstract}

Keywords: dairy cattle farming, smallholder, impact, livelihood

\section{Introduction}

Tanzania is rich in natural resources comprising vast land and a large number of livestock. It occupies 94.5 million hectares of which 88.6 million hectares are covered by land mass and 6.2 million hectares are occupied by water bodies. Out of the 88.6 million hectares of land, 60 million hectares comprise rangelands which have the capacity of occupying up to 20 million livestock and provide over $90 \%$ of the feed resource to the livestock (Kurwijila, 2010). The dairy industry is one of the essential components of the livestock sector in Tanzania. It contributes about one-third of the $4.6 \%$ livestock industry's share to the Gross Domestic Product (GDP) (URT, 2010). 


\section{$\triangle$ AKKAYA

The dairy industry has even greater potential for improving the living standards of people through improved nutrition arising from milk consumption and incomes raised from sales of milk and milk products (Kurwijila et al., 1995). The main dairy animal in Tanzania is cattle which are classified as dairy for those that average about 2000 litres per lactation and dual purpose indigenous cattle producing around 300 - 500 litres and are mostly used for beef which are the majority. In Tanzania, the dairy cattle are kept by smallholder farmers and few medium and large scale farms (Kurwijila, 2010).

Out of the 21 million cattle in Tanzania, about 680,000 are dairy cattle mainly crosses of Friesian, Jersey, and Ayrshire breeds with the Tanzania Shorthorn Zebu (TSZ). Total annual milk production is currently estimated at 1.65 billion litres. About 70\% of the milk produced in Tanzania comes from the traditional sector (indigenous cattle) kept in rural areas, while the remaining 30\% comes from improved cattle mainly kept by smallholder producers (URT, 2011). The government of Tanzania has been continuously employing agricultural extension workers and posting them in different parts within the country so that they have responsibilities of assisting farmers to increase milk production and enhance the market chain of milk products. Such strategy intends to promote dairy farming so that farmers can benefit from the income generated and food nutrients from consumption of dairy products.

According to Salami et al. (2010), the concept of "smallholder farmer" is highly varied economically in the literature. The earnings as high as 50000 USD to purely subsistence farming are inclusive in the definition of smallholder farmer. The physical size of a smallholder farm is also generally vague, but Salami et al. (2010) refer farming systems with a family unit as the center of planning and implementation, operating within a network of relations at the community level. Smallholder farming system also includes farms which are cultivated by less than 2 hectares of land and farmers own only a few heads of cattle or other livestock (Salami et al., 2010).

Good performance of dairy farming is likely to contribute in the improvement of living standard of smallholder dairy farmers particularly in rural areas. Despite the government effort in promoting dairy farming in Tanzania, there is uncertainty regarding the impacts of smallholder dairy cattle farming especially in Sunga ward of the Lushoto District in the West Usambara Mountain areas. The objective of this study was to assess socio-economic impacts of smallholder dairy cattle farming on the livelihood in Sunga ward of Lushoto District, Tanzania.

\section{Literature review}

\section{Theoretical framework}

This study applied Sustainable Livelihood Approach (SLA) theoretical framework to explain socio-economic impacts of smallholder dairy cattle farming on the livelihood in selected villages of Sunga Ward in Lushoto District, Tanzania. The pioneers of this approach are Robert Chambers and Gordon Conway who introduced the approach in 1992. There are three insights into poverty which underpin this new approach. Chambers and Conway (1992) put forward that a livelihood comprises the capabilities, assets (stores, resources, claims and access) and activities required for a means of living. In this study, the activity required for a means of living for a smallholder farmer is dairy cattle farming, capability is skills and assets are such as cattle and land. A livelihood is sustainable if it can cope with and recover from stress and shocks, maintain or enhance its capabilities and assets, and provide sustainable livelihood opportunities (for instance; livelihood opportunities from this study include milk sells, animal sells, manure) for the next generation; and which contributes net benefits to other livelihoods (such as construction of houses, food security, soil conservation, education services and health 


\section{$\triangle$ AKKAYA

services) at the local and global levels and in the short and long term.

Krantz (2001) argues that there is the realization that poverty as conceived by the poor themselves is not just a question of low income, but also includes other dimensions such as bad health, illiteracy, lack of social services, etc. as well as a state of vulnerability and feelings of powerlessness in general. Through Sustainable Livelihood Approach, in the study area, there are households which participate in dairy cattle farming as their basic economic activity. From dairy cattle farming, owners expect to socially and economically improve their livelihoods through using income generated for buying assets (mobile phones, bicycles, motorcycles and television), building or repairing houses, affording home expenses (such as health and education services) and improving food nutrients for their families. Thus, this study intended to assess socio-economic impacts of smallholder dairy farming on livelihood from selected households in Mambo, Nkukai and Kwemtindi villages of Sunga ward in Lushoto District, Tanzania.

\section{Empirical literature review}

Chaudhary \& Upadhyaya (2013) explored socio-economic impacts of dairy cooperative in Adarsha Milk Producer Dairy Cooperative during May 2008 to December 2008. The study sample comprised of 224 dairy farmers to collect qualitative and quantitative data. For primary data, questionnaire, interview schedule and field observation were used as instruments of data collection. The data were analysed descriptively to generate descriptive statistics. The findings show that improved housing, possessing television, telephone, mobile phone, access to electricity, access to drinking water, improvement of toilet and access to food were the main social impacts of dairy farming. The main economic impacts revealed include loan repayment, bank savings and land purchase.

Bikuba (2011) assessed the impact of smallholder dairy cattle farming on socio-economic status of households in the selected villages of the Isagehe Ward of Kahama district Tanzania. A sample of 120 households keeping dairy cattle selected randomly was surveyed using structured questionnaire. Data were coded and analysed through SPSS version 12. The study found that the average annual income of dairy farmers was Tsh. 1568183. Moreover, dairy farming households consumed more protein as well as possess more assets than non-dairy cattle farmers.

Tefurukwa (2011) assessed the impact of a dairy cattle project on the household livelihoods in Kasulu District, Tanzania. The study was purposively selected Muzye and Mnanila wards since they are the project areas. The study sample comprised of 120 respondents in which 60 were dairy cattle owners and 60 were non-dairy cattle owners. The questionnaire was used as an instrument for data collection and data were analysed through descriptive statistics, multiple linear regression and t-test whereby SPSS version 16 was applied. The findings show that there was a significant increase in annual income of project beneficiaries from 471 266.67TZS to 1 012 400.00TZS before and after the beginning of project intervention respectively. In addition to that, the higher increase in income was observed among dairy cattle supported by the project than non-project beneficiaries. Moreover, there was an increase in crop production due to application of cattle manure. Also, income from dairy cattle helped beneficiaries to buy assets such as bicycles.

Mian et al. (2007) examined impacts of dairy farming on livelihood of participating women under the Grameen Bank in selected areas of Rangpur District in Bangladesh. A sample of 60 randomly selected women from 6 villages whom at least one woman possesses one cow bought by the credit from Gremeen Bank. A questionnaire 


\section{AKKAYA}

International Journal of Economics and Management Vol. 1 Issue (2) pp 41 - 49, 2019

(C) Akkaya Science Publishing

was used in gathering of information. The Cobb-Douglas production function model and descriptive statistics were applied in data analysis. The findings show that dairy cattle has impacts on livelihood of women dairy cattle farmers since it contributed to improved access to education for their sons and daughters, building and repairing of houses, serving money and food security.

\section{Conceptual framework of socio-economic impacts of smallholder dairy cattle farming on livelihood}

Dairy cattle farming practiced by a farmer in the study area as zero grazing may contribute to two categories of impacts on smallholder livelihood. There can be social and economic impacts from smallholder dairy cattle farming on livelihood (Figure 1). The social impacts which might be realized by smallholder dairy cattle farmer include education achievement such as children attending school; health security; food availability; and possession of assets such as houses, television and mobile phones. Economic impacts from smallholder dairy cattle farming may comprise livestock sale, milk cash, manure and employment. However, there is an interconnection between social and economic impacts in which economic impacts usually contribute to achieving social impacts through using revenues generated from dairy cattle farming.

Figure 1: Conceptual framework of socio-economic impacts of smallholder dairy cattle farming.

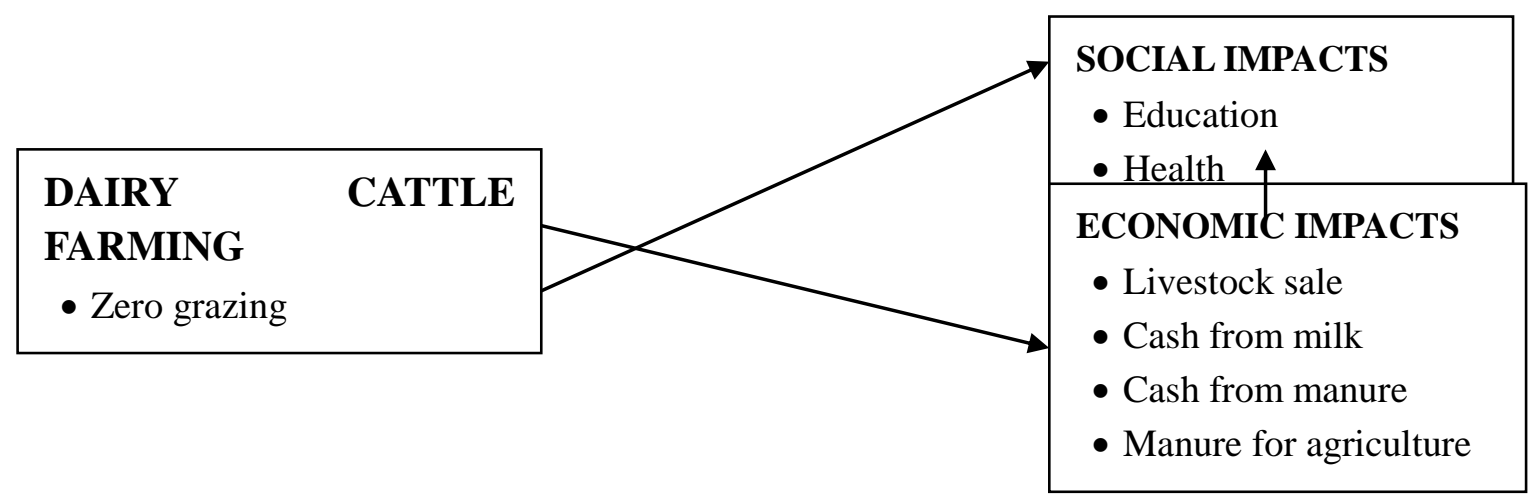

\section{Materials and methods}

The study population included smallholder dairy cattle farming households practicing zero grazing. A cross-sectional study design was adopted for gathering quantitative data. The study use multistage sampling to select Sunga ward of Lushoto district through purposive sampling since it is where sensitization education and technical support have been directed by the government agricultural extension workers to promote dairy cattle farming. Three villages were selected by using simple random sampling from Sunga ward. The names of selected villages are Mambo, Nkukai and Kwemtindi. The study used simple random sampling to select 40 farmers from each village and form the sample size of 120 households from the population of 384 dairy cattle farming households. The study is in line with Reinartz et al. (2009) which proposed a minimum sample size of 100. Adult member of the household was regarded as a respondent of the survey. Structured questionnaire was used as an instrument of data collection. The analysis of data was carried out by using SPSS to reveal descriptive statistics such as means, frequencies and percentages, and paired-samples t-test results.

\section{Results and discussion}

\section{Demographic characteristics}

Demographic characteristics of respondents surveyed include sex, education, household size, marital status, age and number of cows owned as shown in Table 1. 
International Journal of Economics and Management Vol. 1 Issue (2) pp 41 - 49, 2019

(C) Akkaya Science Publishing

Table 1: Demographic characteristics of smallholder dairy cattle farmers

\begin{tabular}{lc}
\hline Demographic characteristic & Response \\
\hline Sex: & $(91) 75.8 \%$ \\
Male & $(29) 24.2 \%$ \\
Female & \\
Education: & $(16) 13.4 \%$ \\
Never attended school & $(100) 83.3 \%$ \\
Primary school education & $(4) 3.3 \%$ \\
Secondary school education & \\
Household size: & $(75) 64.1 \%$ \\
5-8 members & 10 members \\
Maximum & 1 member \\
Minimum & 5 members \\
Average & \\
Marital status: & $(114) 95 \%$ \\
Married & $(3) 2.5 \%$ \\
Single & $(3) 2.5 \%$ \\
Widow & \\
Age: & $(52) 43.3 \%$ \\
$40-59$ years (majority) & 83 years \\
Maximum & 20 years \\
Minimum & 52 years \\
Average & \\
Dairy cattle owned: & $(63) 52.5 \%$ \\
Owning 2 dairy cattle & 5 \\
Maximum & 1 \\
Minimum & 2 \\
Average & \\
\hline Mers & \\
\hline & \\
\hline & \\
\hline
\end{tabular}

Note: Numbers in brackets are frequencies

The majority of farmers who keep dairy cattle participated in the survey comprised males (75.8\%) while females were $24.2 \%$. Based on education, most of the respondents attended primary school education (83.3\%) and $3.3 \%$ completed secondary school education. Few respondents (13.4\%) were illiterate since they never attended school. The dominant household size of smallholder dairy cattle farmers ranges from 5 to 8 members, where as the maximum household size was 10 members and minimum size was 1 member. The average household size was 5 members. In the study area, most of smallholder dairy cattle farmers were married (95\%) while a few respondents were single $(2.5 \%)$ and widows $(2.5 \%)$. The age distribution of respondents indicates that the majority of participants (43.3\%) had 40-59 years, whereas the maximum age was 83 years and the minimum age was 20 years. With regard to dairy cattle owned, $52.5 \%$ of farmers had 2 dairy cattle which are local breeds whereas the average number was 2 cattle. The maximum number of dairy cattle was 5 and the minimum number was 1 cattle. 


\section{A AKKAYA

\section{Social impacts of smallholder dairy cattle farming on livelihood}

The impact of smallholder dairy cattle farming was examined in livelihood aspects including the impact on household food security, paying for health and education services as well as increase of household assets. The study found that a smallholder dairy cattle farming has a social impact on livelihood as shown in Figure 2.

Figure 2: Responses regarding social impacts of smallholder dairy cattle farming on livelihood $(\mathrm{n}=120)$

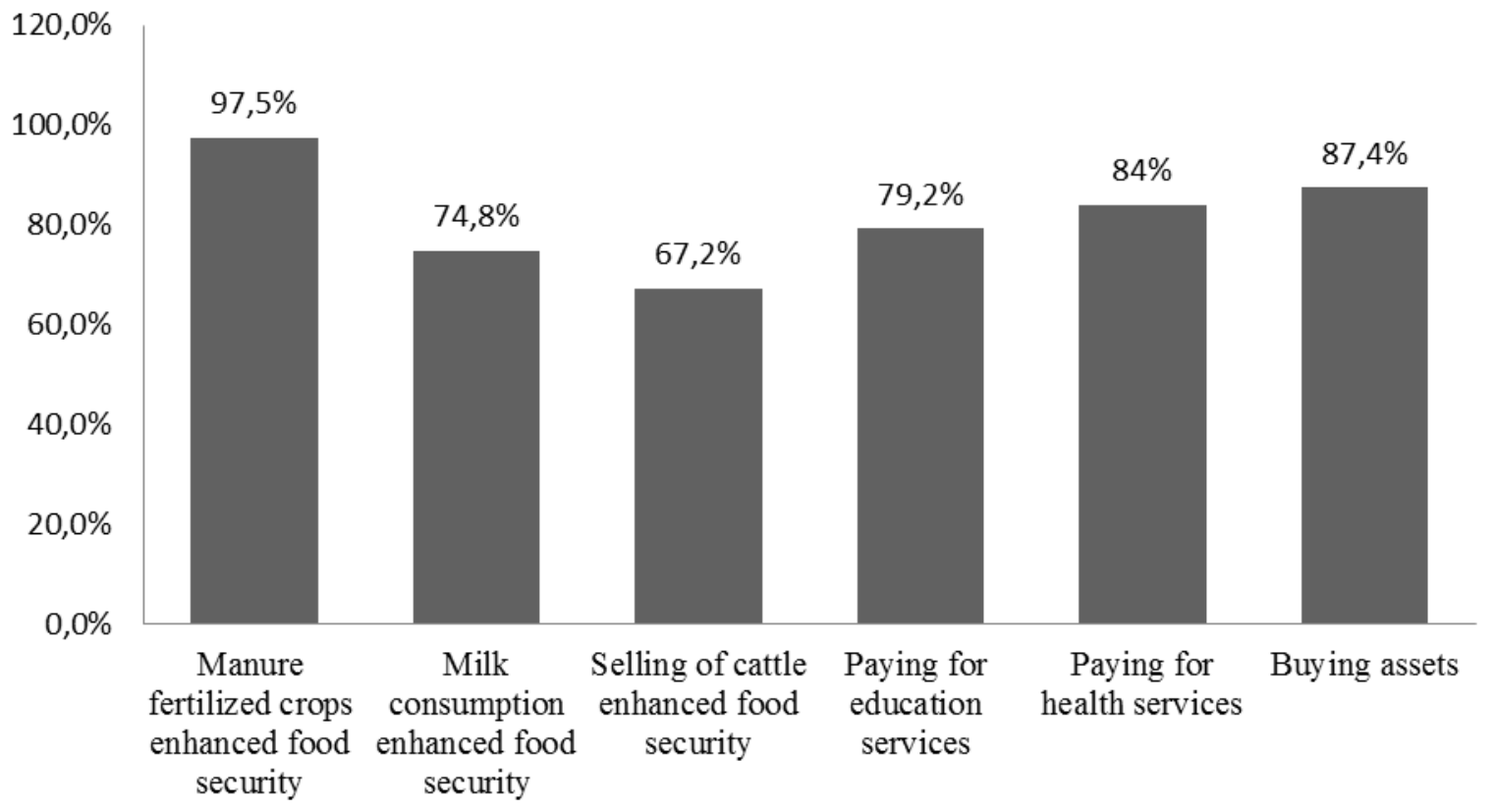

The majority of farmers realized impacts of dairy cattle farming in enhancing household food security through availability of adequate food from improved crop harvest such as improved yields from Irish potatoes, beans and maize following manure application (97.5\%); others use dairy cattle milk for consumption (74.8\%) and 67.2\% of farmers spend money obtained from selling some cattle for food security through buying of food. Also, most farmers (87.4\%) have been using part of the income from dairy cattle for buying assets such as land, motorcycles, other animals such as goats and sheep, chickens and buying house construction materials such as iron sheets and bricks for house construction. Moreover, a dairy cattle farming has an impact on household's access to education and health services. The study revealed that $84 \%$ of respondents said that dairy cattle farming demonstrated high impact in affording paying for health services in families. More findings show that $79.2 \%$ of households depend on dairy cattle in order to have access to improved educational services. Through income obtained from dairy farming, families spent part of money for paying education services including school fees for students and buying other school requirements such as school uniforms and books.

\section{Economic impacts of smallholder dairy cattle farming on livelihood}

The economic impact of dairy cattle farming was examined through income generated from selling of milk, cattle and manure, use of manure for agriculture and farmers' perception regarding dairy cattle farming as an employment. The study revealed that a smallholder dairy cattle farming has economic impacts on livelihood (Figure 3). 


\section{A AKKAYA \\ science publishing}

International Journal of Economics and Management Vol. 1 Issue (2) pp 41 - 49, 2019

(C) Akkaya Science Publishing

Figure 3: Responses regarding economic impacts of smallholder dairy cattle farming on livelihood (n=120)

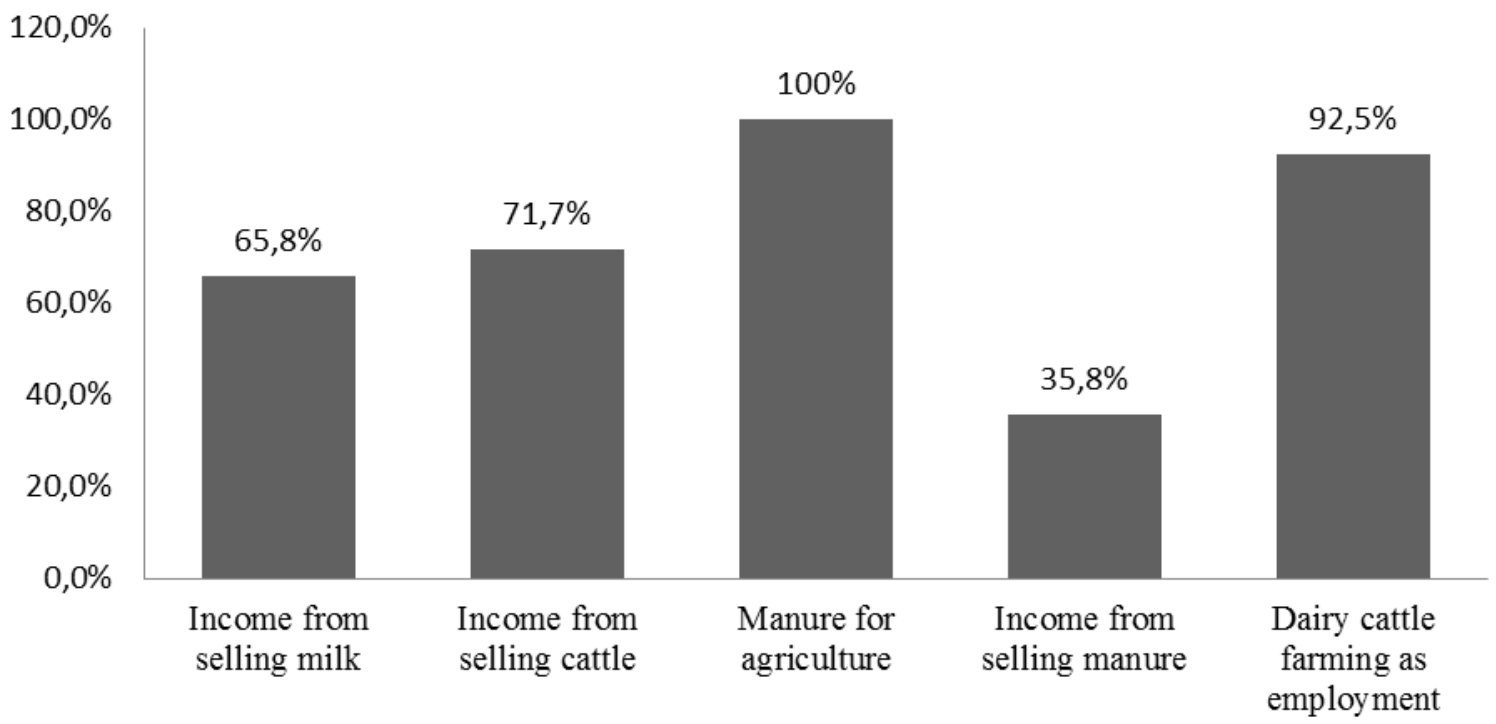

The findings show that farmers $(100 \%)$ said that the economic impact of dairy cattle farming was realized in through the availability of manure for agriculture. Manure from cattle used by farmers on agricultural lands to improve production of cash crops such as Irish potatoes, tomatoes and cabbages, and food crops such as beans and maize. More findings revealed that most of the farmers (92.5\%) regard dairy cattle farming as an important employment for household economic development. They depend on dairy cattle farming as one of employment since it generates income and food for livelihood enhancement in their families. Moreover, the study found that many farmers used to sell some of the cattle (71.7\%) and milk (65.8\%) to improve household income. Part of the income obtained from selling cattle and milk are used by households to buy feeds and improve pastures. The other amount of income from selling cattle and milk is used to improve livelihoods of families. Few farmers (35.8\%) said that they are using some dairy cattle manure to generate household income. This justifies that cattle manure is mostly used for fertilizing agricultural plots.Furthermore, the study examined the impact of smallholder dairy cattle farming on livelihoods in relation to household annual income in Tanzania shillings (TZS). The study found that an average household annual income for smallholder dairy farmers was TZS 1489075 whereas milk from dairy cattle farming contributes about TZS 699437 to this annual household income when the cow produces milk. Such income from milk production in a year is equivalent to $47 \%$ contribution to the household income. This demonstrates that milk produced by dairy cattle has an economic impact on livelihoods of dairy cattle farming households. More other results show that, dairy cattle farming has a positive impact on household income generated from agriculture following the increased in annual income from crops such as Irish potatoes and beans fertilized by cattle manure.

Table 2: Paired samples statistics of household annual income from crops before and after establishing dairy cattle farming

\begin{tabular}{|l|c|c|c|c|}
\hline Paired statements & Mean (TZS) & $\begin{array}{c}\text { Number of } \\
\text { respondents }\end{array}$ & $\begin{array}{c}\text { Std. } \\
\text { Deviation }\end{array}$ & Std. Error Mean \\
\hline $\begin{array}{l}\text { Annual income from crops after } \\
\text { applying cattle manure }\end{array}$ & 555300 & 119 & 527474 & 48353.48 \\
\hline $\begin{array}{l}\text { Annual income from crops before } \\
\text { dairy cattle }\end{array}$ & 166600 & 119 & 191291 & 17535.64 \\
\hline
\end{tabular}




\section{AKKAYA}

International Journal of Economics and Management Vol. 1 Issue (2) pp 41 - 49, 2019

(C) Akkaya Science Publishing

The study found that the average household annual income generated from crops increased to TZS 555300 after the farmer started using dairy cattle manure to fertilize agricultural land compared to TZS 166600 in the period before establishing dairy cattle farming (Table 2). Paired samples $t$ test in Table 3 justify that there is variation in household annual income in the two periods before and after household introduced dairy cattle farming.

Table 3: Paired samples $t$ test showing variation of household annual income before and after the farmer introduced dairy cattle farming

\begin{tabular}{|l|c|c|c|c|c|c|c|}
\hline Paired statements & $\begin{array}{c}\text { Mean } \\
\text { difference( } \\
\text { TZS) }\end{array}$ & Std Deviation & \multicolumn{2}{|c|}{$\begin{array}{c}\text { 95\% Confidence Interval } \\
\text { of the Difference }\end{array}$} & $\mathrm{t}$ & $\mathrm{df}$ & Sig. \\
\cline { 3 - 6 } & & Lower & Upper & & & \\
\hline $\begin{array}{l}\text { Annual income from } \\
\text { crops after applying } \\
\text { manure from dairy } \\
\text { cattle - Income from } \\
\text { crops before dairy } \\
\text { cattle farming }\end{array}$ & & 416223 & 313148 & 464263 & 10.188 & 118 & 0.000 \\
\hline
\end{tabular}

Hence, results revealed by paired sample $\mathrm{t}$ test in Table 3 demonstrate that there is a significant increase household annual in income $(\mathrm{t}=10.188, \mathrm{p}<0.001)$ at $5 \%$ significance level generated from crops fertilized by dairy cattle manure in comparison to the period before the household practicing dairy cattle farming as the annual income increased by TZS 388700 after the farmer introduced dairy cattle farming.

\section{Conclusion}

Smallholder dairy cattle farming in Sunga ward of the Lushoto District has demonstrated socio-economic impacts on the livelihoods of households. The social impacts of dairy cattle were realized in the enhancement of household food security, access to education and health services and households' accumulation of assets. The use of manure from cattle farming to fertilize agricultural lands has contributed to improve crop production and enhance household food security by making food for the family being more available. Consumption of milk produced and the income generated from selling some of the cattle contributed to the increase of access to food among households. Households through income generated from dairy cattle farming managed to pay for education and health services. The economic impact of smallholder dairy cattle farming in the study area was demonstrated through income generated and employment opportunities. From dairy cattle, farmers generate income mainly from selling milk and cattle. They also get income from selling more crops harvested after applying cattle manure to agricultural lands. However, little income is obtained from selling cattle manure since most of it is utilized by farmers on cropping lands. A dairy cattle farming is perceived by farmers as their important employment. This study recommends the government to allocate more extension officers in rural areas, particularly in the Sunga ward so that farmers can obtain sufficient knowledge and skills that may help to promote further the socio-economic impacts of dairy cattle farming for enhancing the livelihood by addressing the abject poverty in rural communities. 


\section{$\triangle A K K A Y A$

\section{References}

1.Bikuba, S.L. (2011). Impact of Dairy Cattle Farming on Household socio-economic Status: A Case of Isagehe Ward in Kahama District, Tanzania. A dissertation for the Award of Master of Arts in Rural Development, Sokoine University of Agriculture, Morogoro, Tanzania.

2.Chaudhary, B. \& Upadhyaya, M. (2013). Socio-economic Impacts of Dairy Cooperative. Economic Journal of Development Issues, Vol.16, No.1-2, pp.15-23.

3.Chambers, R. \& Conway, G. (1992). Sustainable Rural Livelihoods: Practical concepts for the 21st Century. IDS Discussion Paper 296, IDS, Brighton, UK, February 1992.

4.Krantz, L. (2001). The Sustainable Livelihood Approach to Poverty Reduction: An Introduction. Sida: Division of Policy and Socio-economic Analysis, Sweden.

5.Kurwijila, L. R. (2010). An Overview of the Dairy Industry in Tanzania; Situation, Challenges and Expectations. In: Proceedings of the Agricultural Council of Tanzania (ACT) Dairy Stakeholders forum held at Mkonge Hotel, Tanga Tanzania, 10th December 2010.

6.Kurwijila R.L., Mdoe, N., Nyange, D.N., Auerbock, R.M. \& Malya, U.N. (1995). Assessment of Fresh Milk and Milk Products Market and Consumption in Dar es Salaam, The Austro Project Association.

7.Mian, R.U., Fatema, J. and Rahman, H. (2007). Impact of Dairy Farming on Livelihood of Participating Women under Grameen Bank in a Selected Area of Rangpur District in Bangladesh. Indian Journal of Agriculture Economics, Vol.62, No.2, pp.260-271.

8.Reinartz, W., Haenlein, M., Henseler, J. (2009). An Empirical Comparison of the Efficacy of Covariance Based and Variance Based SEM. International Journal of Market Research, Vol.26, No.4, pp.332-344.

9.Salami, A., Kamara, A. B. \& Brixiova, Z. (2010). Smallholder Agriculture in East Africa: Trends, Constraints and Opportunities. African Development Bank.

10.Tefurukwa, K.M. (2011). The Impact of a Dairy Cattle Project on Households'Livelihoods in Kasulu District, Tanzania. A Dissertation for the Award of Master of Arts in Rural Development, Sokoine University of Agriculture, Morogoro, Tanzania.

11.URT (United Republic of Tanzania) (2010). Economic Survey, 2010. Ministry of Finance and Economics, Dar es Salaam.

12.URT (2011). The Tanzania Dairy Industry: Status, Opportunities and Prospects. Paper Presented to the 7th African Dairy Conference and Exhibition held at MovenPick Palm Hotel, Dar es Salaam, 25-27 May 2011, Ministry of Livestock and Fisheries Development, Dar es Salaam. 